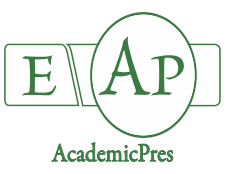

Mechergui K et al. (2021)

Notulae Botanicae Horti Agrobotanici Cluj-Napoca

Volume 49, Issue 1, Article number 12218

DOI: $10.15835 /$ nbha 49112218

Review Article

\title{
Effect of climate change on the spatial distribution and cork production of Quercus suber L., the risk of exclusion by the Aleppo pine expansion, and management practices to protect $Q$. suber habitat: A review
}

\author{
Kaouther MECHERGUI ${ }^{1 *}$, Amal S. ALTAMIMI², Wahbi JAOUADI ${ }^{1,3}$, \\ Souheila NAGHMOUCHI ${ }^{1}$, Youssef AMMARI ${ }^{1}$ \\ ${ }^{1}$ University of Carthage, National Institute of Research in Rural Engineering, Waters and Forests, B.P. 10, Hédi Karray Street, \\ Menzeh IV, Ariana 2080, Tunisia; mecherguikaouther2015@gmail.com (" corresponding author); \\ den_souheila@yahoo.fr;ammari_youssef@yahoo.fr \\ ${ }^{2}$ Princess Norah Bint Abdulrahman University, Biology Department, College of Science Riyadh, \\ Saudi Arabia; amal.alfawaz@gmail.com \\ ${ }^{3}$ University of Jendouba, Silvo-Pastoral Institute of Tabarka, B.P. 328,8110 Tabarka, Tunisia; jaouadiwahbi@gmail.com
}

\begin{abstract}
Climate change represents an important challenge for forest management and the silviculture of stands and it is known that climate change will have complex effects on cork oak forest ecosystems. North Africa and the Mediterranean basin are especially vulnerable to climate change. Under the effect of climate change, cork oak will disappear from a large area in the future, and the rest will migrate to higher altitudes and latitudes. This study aimed to evaluate the effect of climate change on the spatial distribution of Quercus suber $\mathrm{L}$. and cork production in the Mediterranean area, and the risk of its exclusion by the Aleppo pine (Pinus halepensis Mill.) expansion. The literature review showed that up to $40 \%$ of current environmentally suitable areas for cork oak may be lost by 2070, mainly in northern Africa and the southern Iberian Peninsula. Temperature directly influences atmospheric evaporative demand and should affect cork productivity. Precipitation is the main factor that positively influences cork growth and several authors have confirmed the negative effect of drought on this growth. Currently, cork oak habitats are colonized in several places mainly by the Aleppo pine. Under climate change, Aleppo pine is projected to occupy higher altitude sites and several authors have predicted that current and future global warming will have a positive influence on Aleppo pine growth in wet sites. In the future and under climate change, there is a strong possibility that the Aleppo pine will colonize cork oak habitat. Finally, we proposed management practices to protect cork oak against climate change and Aleppo pine expansion.
\end{abstract}

Keywords: Aleppo pine; climate change; cork oak; cork production; expansion; management practices; potential distribution

Received: O8 Jan 2021. Received in revised form: 03 Feb 2021. Accepted: 23 Feb 2021. Published online: 25 Feb 2021.

From Volume 49, Issue 1, 2021, Notulae Botanicae Horti Agrobotanici Cluj-Napoca journal will use article numbers in place of the traditional method of continuous pagination through the volume. The journal will continue to appear quarterly, as before, with four annual numbers. 


\section{Introduction}

Climate change represents an important challenge for ecologists, biologists, and modelers, whose research interest is the study of the potential effect of climate change on ecosystem services provided by forests (Deal et al., 2017; Fréjaville et al., 2019). A rise in the mean temperature and variation in rainfall patterns could modify the current distribution of plant species (Lopez-Tirado et al., 2018). Over the last few decades, the scientific community has become increasingly concerned with climate change. More extreme climatic conditions, such as rising mean temperatures and variations in rainfall patterns, are expected within the present century (IPCC, 2014). The Mediterranean basin is especially vulnerable to climate change (Goubanova and $\mathrm{Li}, 2007)$. Recent climatic projections for the Mediterranean basin predict an air temperature increase and a decline in rainfall, mainly during the summer period, resulting in extended periods of soil water deficit (Gratani et al., 2016; IPCC, 2014). Prolonged dry periods result in a negative soil water balance as the amount of water that evaporates overcomes the amount of water intercepted by the soil through rainfall and summer humidity (Brunetti et al., 2002; Moretti et al., 2015). Species might undergo a marked risk of local extinction with a consequent fragmented distribution, especially in North Africa and Iberia (Benito Garzón et al., 2008; Klausmeyer and Shaw, 2009). If the habitable area is reduced for this species, or the potential for its permanence is predicted to be limited in a given location, other species may establish within the ecosystem (Pons and Pausas, 2006; Lopez Tirado and Hidalgo, 2016a). Tree species may undergo shifts in distribution within a short time owing to the effect of global change. This is especially important for species growing at the boundaries of their current distribution Lopez-Tirado and Fidalgo (2016a). Despite the massive impact of global warming predicted by the models in the southern Mediterranean, some areas would maintain their suitability for species occurrence, thus assuming an important role in terms of biodiversity conservation. These areas might be worthy of a deeper scientific investigation and public awareness for preserving cork oak from extinction. Global climate change affects ecosystems worldwide (Parmesan and Yohe, 2003; Parmesan, 2006). Forest ecosystems are particularly susceptible to shifts in natural disturbance regimes induced by climate change (Dale et al., 2001; Trumbore et al., 2015). Given this, the niche modeling approach could be considered as a promising tool for planning, monitoring, and managing native populations and their habitats (Araujo and Williams, 2000; Costa et al., 2010; Lemes et al., 2014). Climate change will inevitably affect species geographical distribution, change species composition and richness, impact biodiversity, and influence the structure and function of ecosystems (Thuiller et al., 2011; Scheffers et al., 2016). Dyderski et al. (2018) quantified changes in the habitats of 12 European forest tree species, demonstrating that most of these species would face severe habitat contraction due to climate change. Several authors have worked on the decline and dieback of cork oak (Quercus suber L.) forests in the Mediterranean basin: (i) Climate change impacts on cork forest decline in the Mediterranean basin: Cases of drought and/or heat-induced forest mortality, elevated $\mathrm{CO}_{2}$ concentration, high temperatures, water deficit, and (ii) Other factors affecting cork oak forest decline: Anthropic pressure and wildfire insect epidemics and disease problems of cork oak forest regeneration. These authors ignored the phenomenon of the expansion of cork oak forests by other species (colonization), mainly the Aleppo pine in North Africa and in the Mediterranean area, which happens to be the main factor in the degradation of cork oak forests. In this study, we show the following:

(i) Several studies have shown that under the effect of climate change, cork oak will disappear from a large area in the future and the rest will migrate northward as well as to higher altitudes.

(ii) Other studies have shown that the Aleppo pine is too plastic a species and will move in the future to areas with a humid climate.

(ii) Other authors have shown that currently cork oak habitats is colonized in several places mainly by the Aleppo pine.

The questions posed in the present study are as follows: 1) In the future, will Aleppo pine colonize the cork oak habitat under the effect of climate change? 2) Will the studies and modeling of the spatial distribution under the effect of climate change of cork oak and Aleppo pine justify existing hypotheses? 
We aimed to answer the above questions based on current localities and in several others that seem apt for the Aleppo pine to invade cork oak forests under the effect of climate change. We intended to better understand if this is a true threat to cork oak forests in Northern Africa and the Mediterranean basin.

\section{Potential impact of climate change on the spatial distribution of cork oak forest}

The genus Quercus comprises 531 species worldwide (Govaerts and Frodin, 1998). Oaks are widely represented in the northern hemisphere, where they constitute one of the most important groups in terms of ecology, biodiversity, and economy (Axelrod, 1983; Menitsky 2005; Cañellas et al., 2005, 2007; Nixon, 2006). Cork oak (Q. suber L.) is a strictly Mediterranean species distributed in the western Mediterranean basin, between southwestern Europe and northern Africa (Figure 1), a climatic, ecological, and socioeconomic sensitive region (Costa et al., 2014). Cork oak woodland is considered a keystone ecosystem (Vicente and Alés, 2006) while enhancing other important provisioning and regulating ecosystem services (Plieninger et al., 2014). Moreover, cork oak woodland is an important biodiversity hotspot where cork oak is harvested throughout their lifetime for their bark (Oliveira and Costa, 2012), the cork being a valuable global non-timber forest product $(\mathrm{FAO}, 2013)$. Cork oak is an evergreen tree characterized by a thick bark, which grows in Mediterranean sclerophyllous forests (Hidalgo et al., 2008). Cork oak woodlands are agro-silvopastoral systems of high socio-economic and conservation value, typical of the western Mediterranean Basin (Figure 2). They cover approximately 1.5 million hectares across Portugal, Spain, Italy, and France, and 1 million hectares in North Africa between Morocco, Algeria, and Tunisia (Diázetal, 1997; Bugalho et al., 2011). North-facing slopes, abundant annual rainfall, and the original stones that produce acidic soils were the main explanatory variables for cork oak distribution in southwestern Spain (Hidalgo et al., 2008).

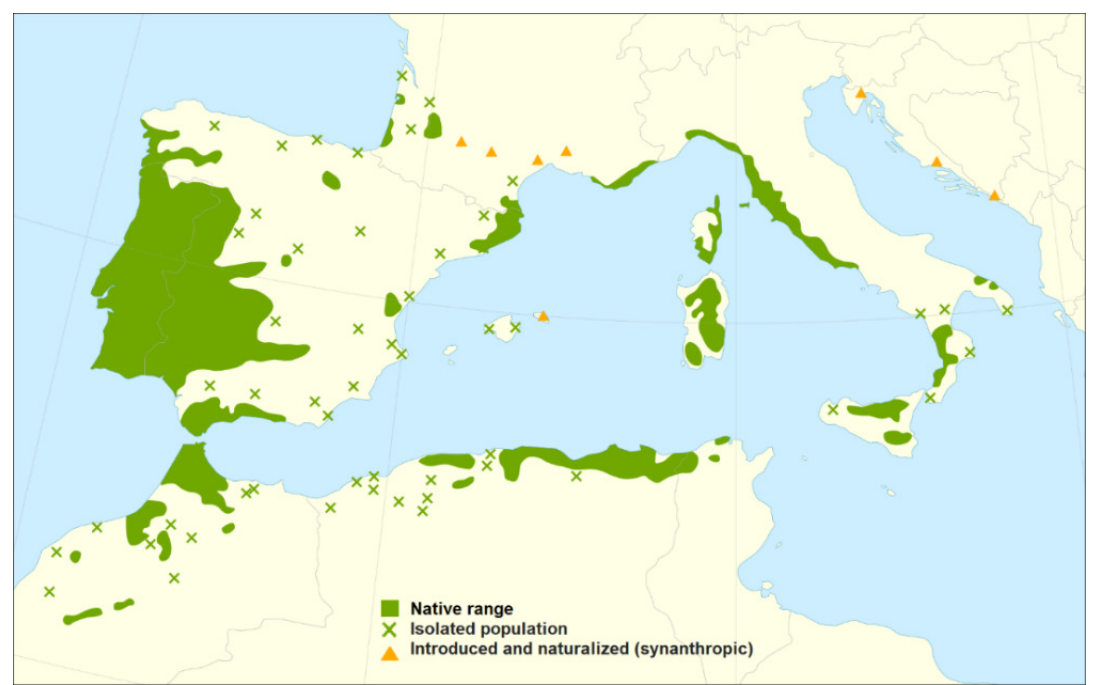

Figure 1. Geographic location of Cork oak in the world (Caudullo et al., 2017) 


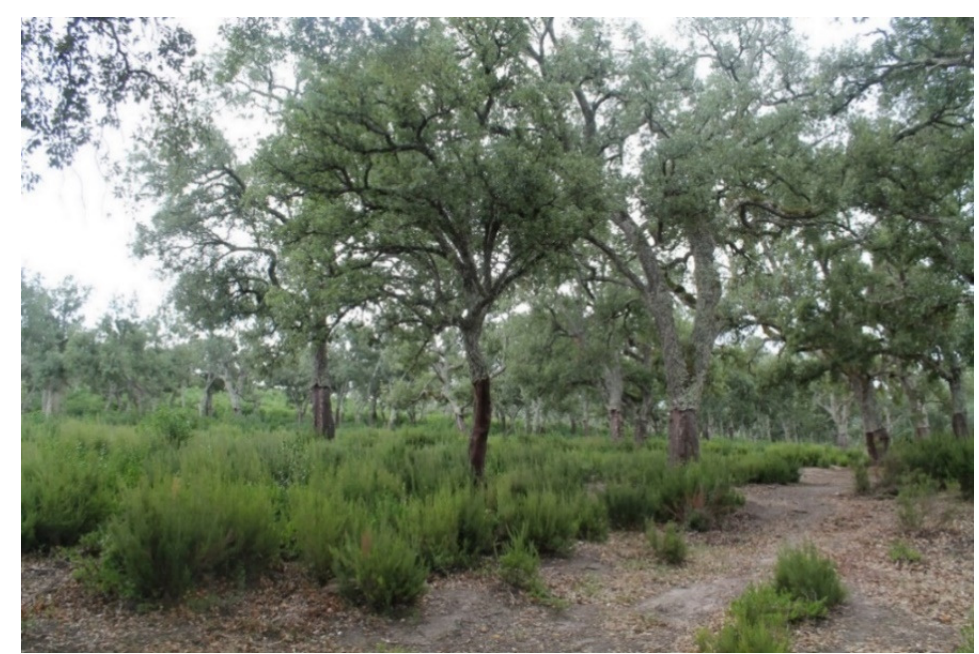

Figure 2. Stand of cork oak in North Africa (Tunisia)

Most of the studies carried out on oak decline in Italy and Spain reported drought as the main driving factor. Although this phenomenon seems generalized and strictly related to site-specific conditions, drought, and in general, ongoing climate warming is identified as the main threat to declining oak stands (Gentilesca et al., 2017). The increase in temperature values and the decrease in precipitation expected for the southern part of the Mediterranean would reduce the habitable areas for cork oak (Vessella et al., 2017). The future distribution of evergreen oaks is most likely driven by climate change (Schirone et al., 2015). Under climate change, the first species that disappears is $Q$. suber a species that does not withstand very low temperatures in continental areas (Costa Tenorio et al., 2005), followed by Quercus coccifera in the inner continental areas (Lopez-Tirado et al., 2018). Using maximum entropy modeling (MaxEnt), Correia et al. (2017) predicted environmentally suitable areas for cork oak (Q. suber) woodlands, a socio-economically important forest ecosystem protected by the European Union Habitats Directive. The authors showed that up to $40 \%$ of current environmentally suitable areas for cork oak may be lost by 2070, mainly in northern Africa and the southern Iberian Peninsula. Almost $90 \%$ of new cork oak stands are predicted to lose suitability by the end of the century, but future plantations can take advantage of increasing suitability in the northern Iberian Peninsula and France. According to Lopez-Tirado et al. (2018) in the predicted future scenarios, cork oak is the species with poleward migration, barely reaching France (only a small suitable area on the Atlantic coast). The authors showed that under climate change, Q. suber dominates mainly in Portugal and along a belt following the south Atlantic coast of Spain. Vessella et al. (2017), in a study of cork oak in the face of climate change in the Mediterranean area, showed that the results of eight combined ecological modeling techniques and two global circulation models highlight a broad contraction of the species potential range over the twenty-first century, both under intermediate and high emissions scenarios. The authors found that coupled northward and upward shifts were predicted, mostly pertaining to Iberia and North Africa and the potential areas detected at Levantine will likely undergo disappearance. The Mediterranean region is projected to be extremely vulnerable to global change, which will affect the distribution of typical forest types such as native oak forests (Acácio et al., 2016). Climatic extremes are also important predictors of oak forest changes, namely extreme temperatures for evergreen oak forests and deficit of precipitation for deciduous oak forests (Acácio et al., 2016). In fact, according to Lopez-Tirado et al. (2018), evergreen oaks could benefit from global change, making up larger mixed forests than the current ones. The influence of global warming is also imprinted into the upward shift in elevation, which would be experienced by cork oak, mostly in the southwestern part of its potential suitable area (Vessella et al., 2017). 
The increased concentration of greenhouse gases in the atmosphere is acknowledged as one of the main reasons for the observed global climatic change. This phenomenon significantly affects the species geographical distribution and changes their richness distribution pattern (Sun et al., 2020). Costa Tenorio et al. (2005) showed that although holm oak and cork oak forests are estimated to have spanned up to 30 million hectares in the past, their current distribution is limited to about 2-3 million hectares worldwide. However, according to Vericat et al. (2012), Mediterranean oak formations presently occupy around 7.3 million hectares. Drought and temperature instability could pose a threat to the distribution of Q. suber L., inducing shifts and reductions of distribution ranges, thus eventually changing the richness distribution pattern (Sun et al., 2020). The authors showed that the distribution center of $Q$. suber $\mathrm{L}$., is migrating towards the northeast in response to climate change. This has also been confirmed by numerous studies of different species in different regions (Peñuelas and Boada, 2003; Vessella and Schirone, 2013; Dyderski et al., 2018). Under climate change, the southern areas of the current distribution of oak corks will be the most affected, including Alentejo and Algarve in Portugal, Extremadura, and Andalucía in Spain, and most of North Africa (Correia et al., 2017). In the southernmost region, which includes North Africa and parts of Iberia, the expected decrease in suitability is so great that resources should be concentrated in the preservation of the few refuges where microclimatic conditions will maintain long-term suitability for the species (Dobrowski, 2011). In the Mediterranean climatic region, a warming condition is forecasted, and the distribution of native oak forests could be affected (Lopez-Tirado et al., 2018). In the period between 1966-2006, a given area of cork oak forest in Portugal was altered mostly to pine and eucalyptus (Acácio et al., 2016). Pecchi et al. (2020) showed that the analyses reported an unchanged amount of total land suitability for forest growth in mountain areas, while smaller values were predicted for valleys and floodplains compared to high-elevation areas. The authors showed that pure woods were predicted as the most influenced when compared with mixed stands, which are characterized by greater species richness. Therefore, a higher level of biodiversity and resilience reduces the threats of climate change on a forest. In southern Spain, Lopez-Tirado and Fidalgo (2016a) showed that under climate change effects, cork oak and gall oak underwent a drastic potential reduction. On the other hand, the Pyrenean oak and Algerian oak might find shelter at higher elevations. By exception, holm oak exhibited the opposite trend and was favored by projected global warming. This projection is rather adverse for biodiversity and oakdependent ecosystems. Acácio et al. (2016) showed that under increasing human pressure and forecasted climate change, evergreen oak forests will continue to decline and deciduous oak forests will be replaced by forests dominated by more xeric species. According to Sun et al. (2020), climate change affects the richness distribution pattern of oaks (Q. suber L.), and these species may migrate to higher altitudes or higher latitudes. The high percentage of species lost is the reason for the higher turnover values in the mountainous areas, while other regions are mostly influenced by the high percentage of species gained associated with the northward shift of species. Predicting changes in the richness distribution pattern of $Q$. suber $\mathrm{L}$. as a result of climate change can help to understand the biogeography of $Q$. suber $\mathrm{L}$. and enact conservation strategies to minimize the impacts of climate change (Sun et al., 2020).

\section{The cork production of Quercus suber $\mathrm{L}$.}

\section{Climate-growth relationships}

Cork oaks are well-known for cork production (Figure 3), a non-wood forest product of high industrial value that economically strengthens the otherwise fragile production regions (Oliveira et al., 2016). Cork is a biological material with a rather unique set of properties that gave it worldwide recognition as a wine sealant and insulator (Fortes et al., 2004; Pereira 2007, 2015). During summer droughts, Mediterranean oak transpiration is mainly supplied by direct groundwater and subsoil water uptake through deep roots (David et al., 2007, 2013). On the other hand, Besson et al. (2014) reported that the accumulated tree transpiration matched the precipitation in spring at the stand level and suggested that the cork oak trees rely on water sources 
from precipitation during the peak of the growing season that is made available to the many superficial roots. Temperature directly influences atmospheric evaporative demand and should affect cork productivity (Rambal et al., 2003). Cork growth recorded a high climate signal, with highly significant and coherent responses to the yearly climate-related sources of variation (Costa et al., 2016). The authors concluded that the high mean sensitivities and inter-series correlations found for cork ring chronologies combined with the significant variance explained by climate variables suggest that climate is likely one dominant signal that affects cork growth, but local environmental stresses can decisively affect this climate signal.

Oliveira et al. (2016) showed that precipitation is the main factor positively influencing cork growth in the Coruche region, one of the major cork production areas in Portugal. Temperature had a positive influence on growth at the beginning of post-dormancy phellogen activity (until April) but exerted a negative influence during the growth period (from May to August). The authors suggest that cork growth is strongly hindered by drought conditions related to spring precipitation. Precipitation and temperature have been recently found to be clearly imprinted in cork rings (Oliveira et al., 1994; Caritat et al., 1996, 2000; Costa et al., 2003, 2015). Unlike the wood rings, which are often faint and indistinct (Natividade, 1950; Sousa et al., 2009), cork rings have clear boundaries and climate seems to be the dominant signal. Ghalem et al. (2018) suggested that cork growth encodes a climatic signal and drought-driven cork growth reduction is a threshold function of the precipitation-temperature ratio, and with an expected increase in drought occurrence under changing climate conditions, cork growth is likely to be similarly affected in Mediterranean regions. Lack of precipitation effectively reduces soil water availability and lowers groundwater levels and, thus, directly constrains the corkring widths that are formed in each growing season, with important implications for cork yield (Mendes et al., 2016).

Leite et al. (2019) confirmed the outcomes of several studies on the negative effects of drought on cork growth (Caritat et al., 1996; Costa et al., 2016; Oliveira et al., 2016), reinforcing that spring and winter rain strongly influence phellogen activity. Ghalem et al. (2018) found precipitation-temperature index thresholds below which cork growth should be constrained in drier climatic conditions. The climate/growth relationships are remarkably strong in young trees (<30 years) of Q. suber (Leal et al., 2008). A strong direct cork growth response has been found to be connected to the previous year's winter precipitation (Caritat et al., 1996, 2000; Costa et al., 2001), together with a generally inverse relationship with monthly (summer) temperature (Caritat et al., 2000). Costa et al. (2016) showed that climate is likely the dominant signal affecting cork growth in mature trees under cork exploitation. However, a similar direct effect of precipitation on cork growth across Mediterranean environments may not be straightforward, because limiting local environmental stresses, related to (soil) water availability, would affect the strength of climate signals on cork rings. Most of the studies carried out on oak decline in Italy and Spain reported drought as the main driving factor (Gentilesca et al., 2017). The authors concluded that although this phenomenon seems generalized and strictly related to site-specific conditions, drought, and in general, ongoing climate warming is identified as the main threat to declining oak stands. Declining oak trees are often characterized by a reduction in ring width, mostly due to the absence or low production of late-wood in ring-porous species (Gentilesca et al., 2017).

\section{Cork-ring growth}

The average cork-ring widths are between 2.2 and $4.8 \mathrm{~mm} \mathrm{yr}^{-1}$ in southwestern Portugal reported at the national (Portugal) level (Ferreira et al., 2000). In Algeria growth is between $0.8 \mathrm{~mm} \mathrm{yr}^{-1}$ and $3.2 \mathrm{~mm} \mathrm{yr}^{-1}$ (Dehane, 2012) (Table 1). In Spain, the cork ring width averages are between 2.2 and $4.8 \mathrm{~mm} \mathrm{yr}^{-1}$ and ranged between 1.85 and $5.25 \mathrm{~mm} \mathrm{yr}^{-1}$ (Costa et al., 2016; Caritat et al., 2000). The annual average cork growth (2.43 $\mathrm{mm}$ ) was in line with that mentioned in the European Research Project (CORKASSESS, 2001). In Spain (Andalusia and Catalonia), the annual growth was an average of $3.1 \mathrm{~mm}$, ranging between 2.0 and $4.8 \mathrm{~mm}$ (Table 1). In Sardinia (Italy) and Corsica (France), the averages were 2.6 and $3.4 \mathrm{~mm}$, respectively, ranging between values of 2.3 and $2.8 \mathrm{~mm}$ and 2.8 and $4.4 \mathrm{~mm}$, accordingly (Chorana et al., 2019). Considering only the growth of cork, the accumulated radial increment of cork during the 10 years of the production cycle ranged 
between 18 and $42 \mathrm{~mm}$ among individual trees, with an average of $26.50 \mathrm{~mm}$ Chorana et al. (2019). This value was lower than the values shown in previous studies (Ferreira et al., 2000; Aloui et al., 2006): in Portugal (33. Eight $\mathrm{mm})$, Spain $(31.7 \mathrm{~mm})$, Morocco $(31.5 \mathrm{~mm})$, and Tunisia $(28.9 \mathrm{~mm})$. In addition, it was also noted that in Algeria, the thicknesses of cork in the northwest were much lower than those of the center $(32.85 \mathrm{~mm})$, and East $(32.21 \mathrm{~mm})$ of the country (Dehane and Ghefar, 2017). In a study of the average annual cork-ring width, Leite et al. (2019) showed that the mean value of the entire sample was $3.30 \pm 1.44 \mathrm{~mm}$. The values found for cork ring width by different authors are in the range of 2.8 to $3.6 \mathrm{~mm}(3.30 \mathrm{~mm}$ and $3.56 \mathrm{~mm}$ by Caritat et al. (2000); $3.8 \mathrm{~mm}$ by Costa et al. (2002); $3.5 \mathrm{~mm}$ by Pereira (2007); $3.3 \mathrm{~mm}$ by Oliveira et al. (2016); $3.6 \mathrm{~mm}$, $3.1 \mathrm{~mm}$, and $2.8 \mathrm{~mm}$ by Costa et al. (2016)). In a large cork sampling covering all the production regions in Portugal, a mean value of cork ring width of $3.6 \mathrm{~mm}$ was reported ranging from site means of $1.6 \mathrm{~mm}$ to 4.6 mm (Lauw et al., 2018).

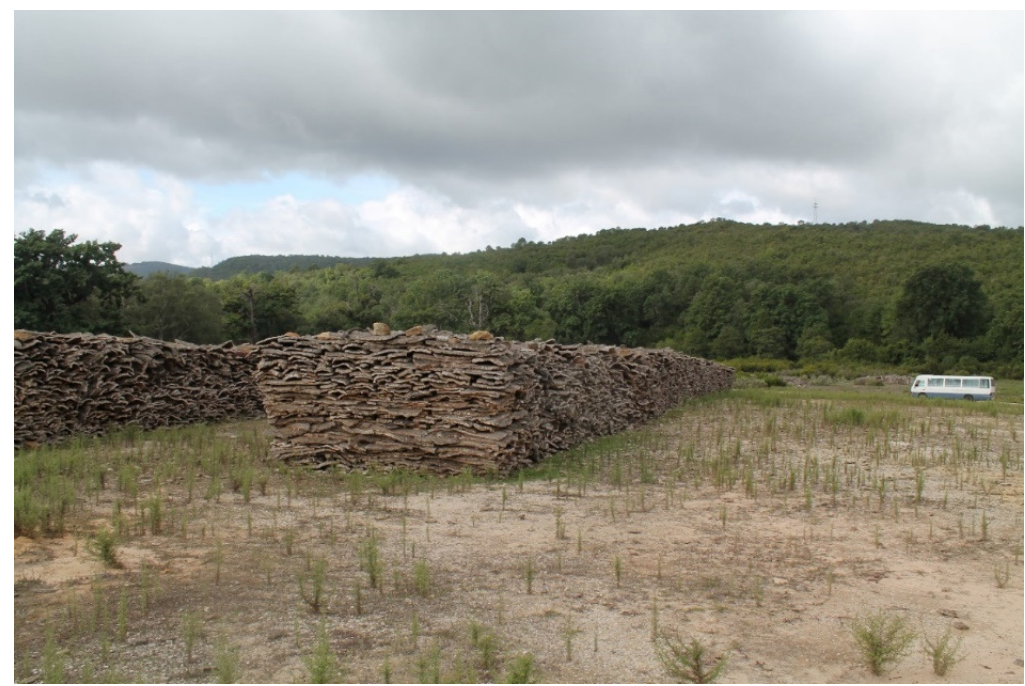

Figure 3. Cork production in North Africa (Tunisia)

Table 1. The annual average cork ring widths

\begin{tabular}{|c|c|c|}
\hline Countries & The annual average cork ring widths & Authors \\
\hline \multirow{3}{*}{ Algeria } & Between $0.8 \mathrm{~mm} \mathrm{yr}^{-1}$ and $3.2 \mathrm{~mm} \mathrm{yr}^{-1}$ & Dehane (2012) \\
\hline & Between 1.9 and $2.6 \mathrm{~mm} \mathrm{yr}^{-1}$ & Ghalem et al. (2018). \\
\hline & $2.6 \mathrm{~mm} \mathrm{~mm} \mathrm{yr}^{-1}$ & Chorana et al. (2019) \\
\hline \multirow{5}{*}{ Spain } & Between 2.2 and $4.8 \mathrm{~mm} \mathrm{yr}^{-1}$ & Ferreira et al. (2000) \\
\hline & Between 1.85 and $5.25 \mathrm{~mm} \mathrm{yr}^{-1}$ & Caritat et al. (2000) \\
\hline & Between 2.0 and $4.8 \mathrm{~mm} \mathrm{yr}^{-1}$ & $\begin{array}{c}\text { European Research Project } \\
\text { (CORKASSESS, 2001) }\end{array}$ \\
\hline & Between $3.30 \mathrm{~mm}^{2}$ and $3.56 \mathrm{~mm} \mathrm{yr}^{-1}$ & Caritat et al. (2000) \\
\hline & Between 1.85 and $5.25 \mathrm{~mm} \mathrm{yr}^{-1}$ & Costa et al. (2016) \\
\hline \multirow{7}{*}{ Portugal } & Between 2.2 and $4.8 \mathrm{~mm} \mathrm{yr}^{-1}$ & Ferreira et al. (2000) \\
\hline & The mean is $3.5 \mathrm{~mm} \mathrm{yr}^{-1}$ & Pereira (2007) \\
\hline & The annual average of 1.6 and $2.3 \mathrm{~mm} \mathrm{yr}^{-1}$ & Dehane (2012) \\
\hline & The means is $3.3 \mathrm{~mm} \mathrm{yr}^{-1}$ & Oliveira et al. (2016) \\
\hline & Between $1.6 \mathrm{~mm}$ to $4.6 \mathrm{~mm} \mathrm{yr}^{-1}$ & Lauw et al. (2018). \\
\hline & Between 3.8 and $4.3 \mathrm{~mm} \mathrm{yr}^{-1}$ & Chorana et al. (2019). \\
\hline & Average $3.30 \mathrm{~mm} \mathrm{yr}^{-1}$ & Leite et al. (2019) \\
\hline Italy & Between 2.6 and $3.4 \mathrm{~mm} \mathrm{yr}^{-1}$ & Chorana et al. (2019). \\
\hline France & Between 2.8 and $4.4 \mathrm{~mm} \mathrm{yr}^{-1}$ & Chorana et al. (2019). \\
\hline \multicolumn{3}{|c|}{ The accumulated radial increment of cork during the 10 years } \\
\hline
\end{tabular}


Mechergui K et al. (2021). Not Bot Horti Agrobo 49(1):12218

\begin{tabular}{|c|c|c|}
\hline Algeria & $32.21 \mathrm{~mm}$ & Dehane and Ghefar, 2017 \\
\hline Portugal & $33.8 \mathrm{~mm}$ & \multirow{2}{*}{ Ferreira et al. (2000); Aloui et al. } \\
Spain & $31.7 \mathrm{~mm}$ & (2006) \\
\hline Morocco & $31.5 \mathrm{~mm}$ & \\
\hline Tunisia & $28.9 \mathrm{~mm}$ & \\
\hline
\end{tabular}

\section{Potential impact of climate change on the spatial distribution of Aleppo pine}

In one study, the potential distribution of three Mediterranean pine species (Pinus pinea L., Pinus halepensis Mill., and Pinus pinaster Aiton) in southern Spain in response to the forecasted increase in aridity was explored. Lopez-Tirado and Hidalgo (2016b) showed that the results predict a wider distribution of stone pine, which could expand its potential area in southern Spain. In contrast, Aleppo pine, especially cluster pine, would reduce their present distribution, with cluster pine occupying sites at higher altitudes. Pine forests are mainly concentrated in sites with poorly developed soils and under harsh climatic conditions (Cabezudo Artero and Perez Latorre, 2004). Largescale reforestation, however, has led to the introduction of pines in potential areas for oaks (Lopez-Tirado and Hidalgo, 2016b). The thermophilous nature of Aleppo pine will probably hinder migration to higher altitude sites (Lopez Gonzalez, 2007). Similar poleward and upward migration trends have also been projected by other authors (Parmesan and Yohen, 2003; Lenoir et al., 2008; Bertrand et al., 2012; Rabasa et al., 2013) and in addition, Aleppo pine is reported as the most suitable species for the most desertification prone zones (Lopez-Tirado and Hidalgo 2016b; Fons-Esteve and Paramo, 2003). Garah and Bentouati (2019) showed that the annual thermal amplitude followed by altitude appears to be the main factor affecting the spatiotemporal distribution of Aleppo pine in the study area. The authors showed that future predictions expect an extension of the areas classified as "moderately favorable" to the Aleppo pine. The authors concluded that in response to climate change, the Aleppo pine may display two contrasting tendencies: a progressive evolution in the north, and a regressive evolution in the south of the Aurès region (Algeria), as well as a displacement of suitable areas for Aleppo pine to the north. In this context, this result coincides with the findings of Vennetier et al. (2011), who predicted that current and future global warming will have a positive influence on Aleppo pine growth in wet sites and negative effects in dry sites. In such cases, the Aleppo pine would reduce its present distribution in the lowest altitude areas (Garah and Bentouati, 2019). This was also predicted by Vennetier et al. (2005) and observed by Tirado and Hidalgo (2016) for pine species located in the southern shore of the Mediterranean.

\section{Aleppo pine expansion in cork oak habitat}

Biological invasions are dynamic processes whose extent and impact commonly increase over time, while the chances of effective intervention are reduced. The invasion of plants in mountainous areas is a particular challenge that has been increasing due to climate change and their use for tourism, among other reasons (Becker and Bugmann, 2001). Invasive species are recognized as one of the main causes of erosion of global biodiversity, and also threaten economies and human health (Millennium Ecosystem Assessment, 2005). Invasive species can profoundly affect ecological communities and processes, potentially leading to rapid or irreversible changes in trophic complexity and structure (Rodewald and Arcese, 2016). Historically, human activities have caused the accidental or planned dispersal of many species beyond their original distribution ranges, and this process is presently at its highest expression (Zalba et al., 2008). Invasion changes the diversity of ecosystems and affects the provision of certain services (Simberloff et al., 2010). In general, environmental factors that prevent or facilitate invasions are predictable, but other factors may be present that ultimately determine the success or failure of Pinaceae invasion, such as biotic interactions (Nunez et al., 2017). Mechanical control of pine trees requires a high level of diligence to be successful. All invasive pines need to be cleared from a site and all green 
foliage (when trees are felled or cut) must be removed, or trees need to be completely removed from the soil (when hand pulled) to avoid regrowth (Ledgard, 2009). Understanding the dispersal ability of an invasive species is a major challenge in attempting to predict its future potential spread (Munzbergova et al., 2010).

The impacts of pine invasions have been widely recognized (Langdon et al., 2010). Pines show similar invasion processes throughout the world, involving two main stages: (a) immigration and establishment and (b) population growth/expansion (Richardson et al., 1994). Other impacts related to pine invasions include the reduction of structural diversity, the increase in biomass, the disruption of prevailing vegetation dynamics, and changes in nutrient cycling (Mack et al., 2000; Peterken, 2001; Richardson, 2001). The successful establishment of pines and their ability to invade natural ecosystems are influenced by climate, topography, and disturbance regimes such as fires and herbivory (de Villalobos et al., 2011). By definition, expansive species are species that increase their distribution and colonize new habitats in a geographical area where they are native (Prach and Wade, 1992; Pyšek et al., 2004). Although the effects of alien invasive plants on ecosystems and biodiversity lead to economic losses (Didham et al., 2005) and have a strong negative effect on global biodiversity (Woziwoda et al., 2014; Van der Meersch et al., 2020), expansion by indigenous species can have detrimental consequences on biodiversity through the reduction in ecosystem productivity, leading to a loss of various ecological goods and services, loss of genetic diversity, and decline in the abundance of populations of affected species (Pyšek et al., 2004; Simberloff, 2010; Kelbel and Adamcikova, 2011).

In Tunisia, we observed the phenomenon of Aleppo pine expansion in cork oak forests in several habitats (Figures 4 and 5). Intensive regeneration of Aleppo pine under cork oak was also observed (Figures 6 and 7). According to Nathan et al. (1999) and Nathan and Ne'eman (2004), mean relative humidity and maximum temperature are good predictors of the release of $P$. halepensis seeds in the Mediterranean basin. The earlier release of seeds in the high areas could result in higher growth rates in this habitat, at least during the initial stages of colonization of new sites (Lavi et al., 2005) and in greater risks of long-distance dispersal, considering that the peaks act as take-off sites for seeds (Ledgard, 1988; Buckley et al., 2005). de Villalobos and Schwerdt (2020) showed that the effects of grazing of feral horses promote the invasion of $P$. halepensis and have provided some key information that allow the elaboration of management recommendations to avoid the propagation of $P$. halepensis. $Q$. suber is a Mediterranean species, and while it is widespread around the world, these areas are within the natural distribution of $P$. halepensis, and thus, the danger for the species replacement from $P$. halepensis invasion is high. This is the same case for the invasion of $P$. pinea by $P$. halepensis mentioned by several authors (Athanasiadis and Gerasimidis, 1986; Barbero et al., 1998; Tapias et al., 2004). Richardson and Higgins (1998) showed that Aleppo pine invasion can result in substantial changes in the invaded ecosystems, a decrease in biodiversity and complexity of ecosystems (Higgins and Richardson 1998; Higgins et al., 1999; Richardson and Higgins, 1998), increased biomass and consequently in fire events (Richardson and Higgins, 1998), negative impact on water resources (le Maitre et al., 1996), changes in soil properties, and the availability and flow of nutrients in the ecosystem (Richardson and Higgins, 1998). 


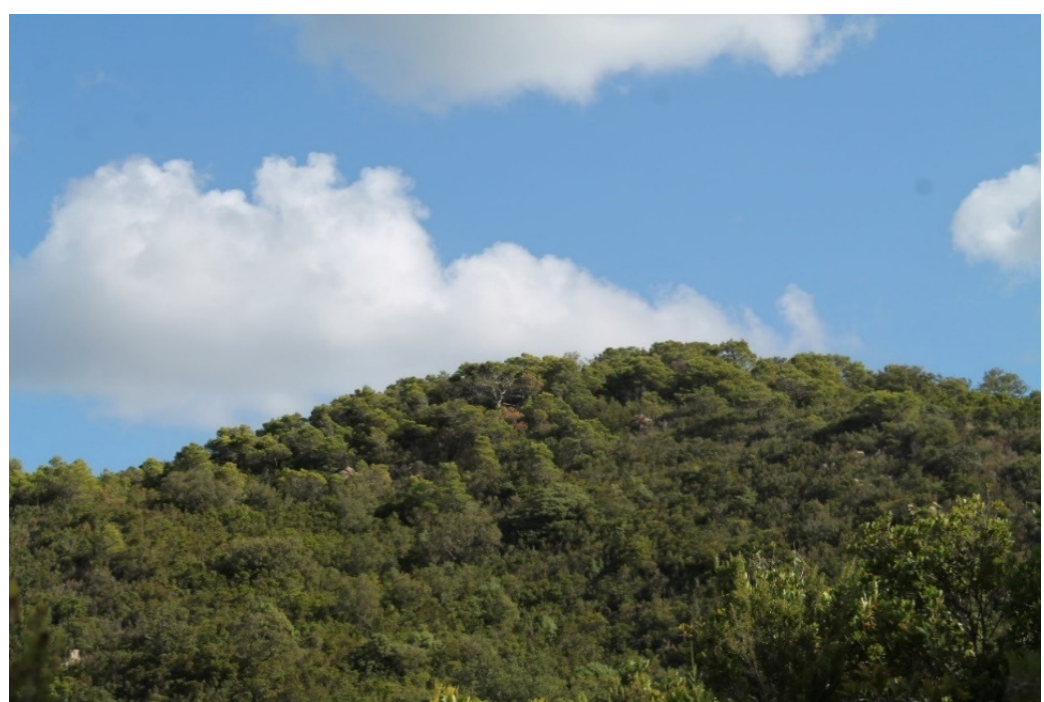

Figure 4. Expansion of Aleppo pine in cork oak habitat in upstream of the mountain: North Africa (Tunisia)

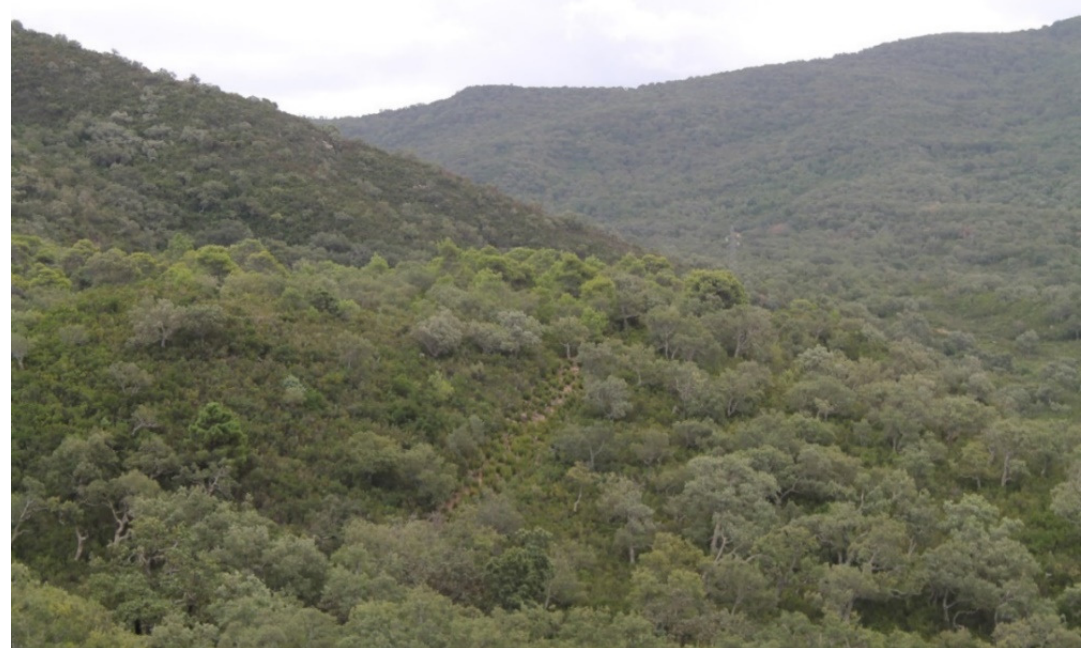

Figure 5. Expansion of Aleppo pine in cork oak ecosystem in downstream of the mountain: North Africa (Tunisia) 


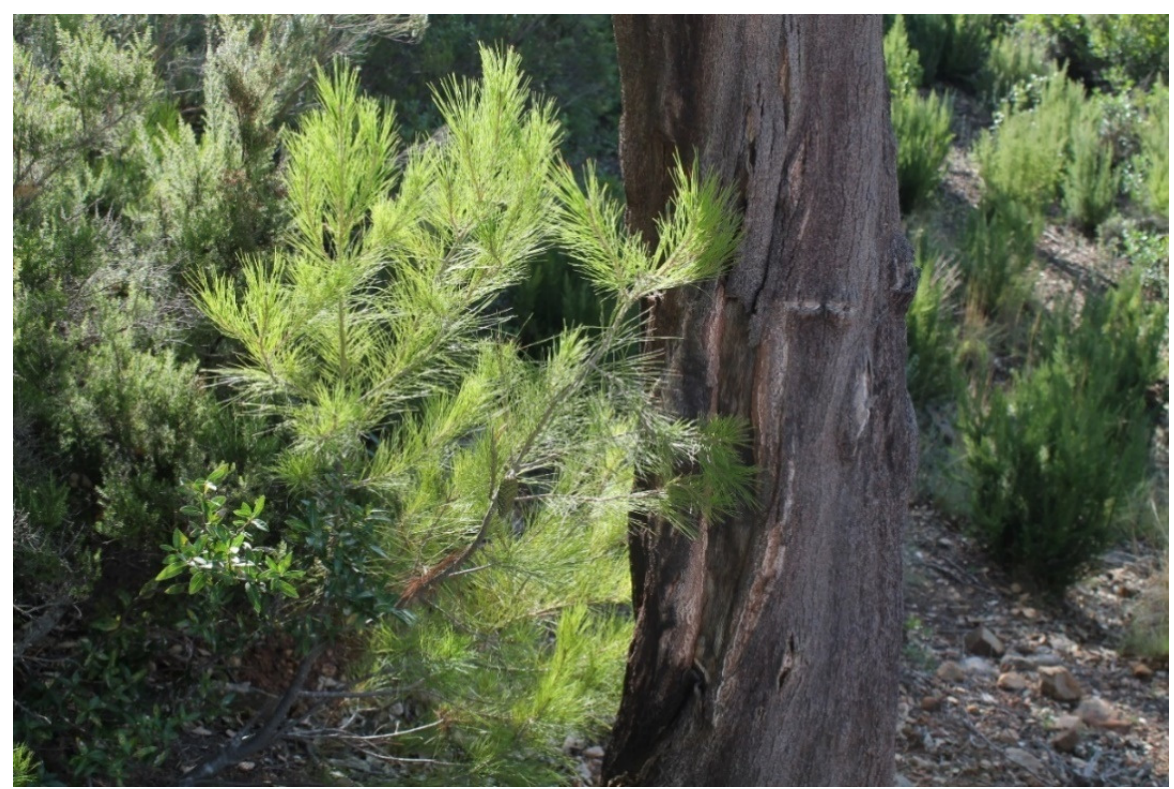

Figure 6. Regeneration of Aleppo pine under cork oak in Tunisia

\section{Management practices to limit the effects of climate change and the expansion effect into cork oak habitat}

\section{Management practices to limit the effect of climate change}

Unlike early successional species, oaks might show considerable time lags in adjusting their ranges due to extremely slow migration rates (Delzon et al., 2013; Gerber et al., 2014). Current cork oak populations will therefore mostly rely on existing phenotypic plasticity, genetic diversity, and adaptation to respond to the expected scenario (Ghalambor et al., 2007; Aitken et al., 2008; Crispo, 2008; Alberto et al., 2013; Kremer et al., 2014; Bussotti et al., 2015). Several provenance tests demonstrated the occurrence of the species local variability at several phenotypic and ecophysiological traits (Varela, 2001; Aranda et al., 2005, 2007; Gandour et al., 2007; Ramırez-Valiente et al., 2010, 2011). A sustainable forest management strategy may reduce the potential impact of climate change on forest ecosystems (Pecchi et al., 2020). Silvicultural practices should be aimed at increasing species richness and favoring hardwoods currently growing as dominant species under conifer canopy, stimulating natural regeneration, gene flow, and supporting (spatial) migration processes (Pecchi et al., 2020). The models indicate that climate change will cause major shifts in the global distribution of cork oak woodlands. It is necessary to start addressing such shifts with appropriate mitigation and adaptation measures, as this ecosystem is particularly important for the rural economy and conservation of biodiversity in much of the western Mediterranean Basin (Bugalho et al., 2011). The following practices proposed by Gentilesca et al. (2017) could enhance the resilience of susceptible oak stands in drought-prone Mediterranean areas: (i) controlling the understory vegetation through targeted cuts and controlled grazing; (ii) reducing aboveground biomass through selective thinning; (iii) anticipating regeneration cuts to stimulate seed dispersal and promote sexual regeneration; and (iv) shortening the rotation period of coppice stands. 


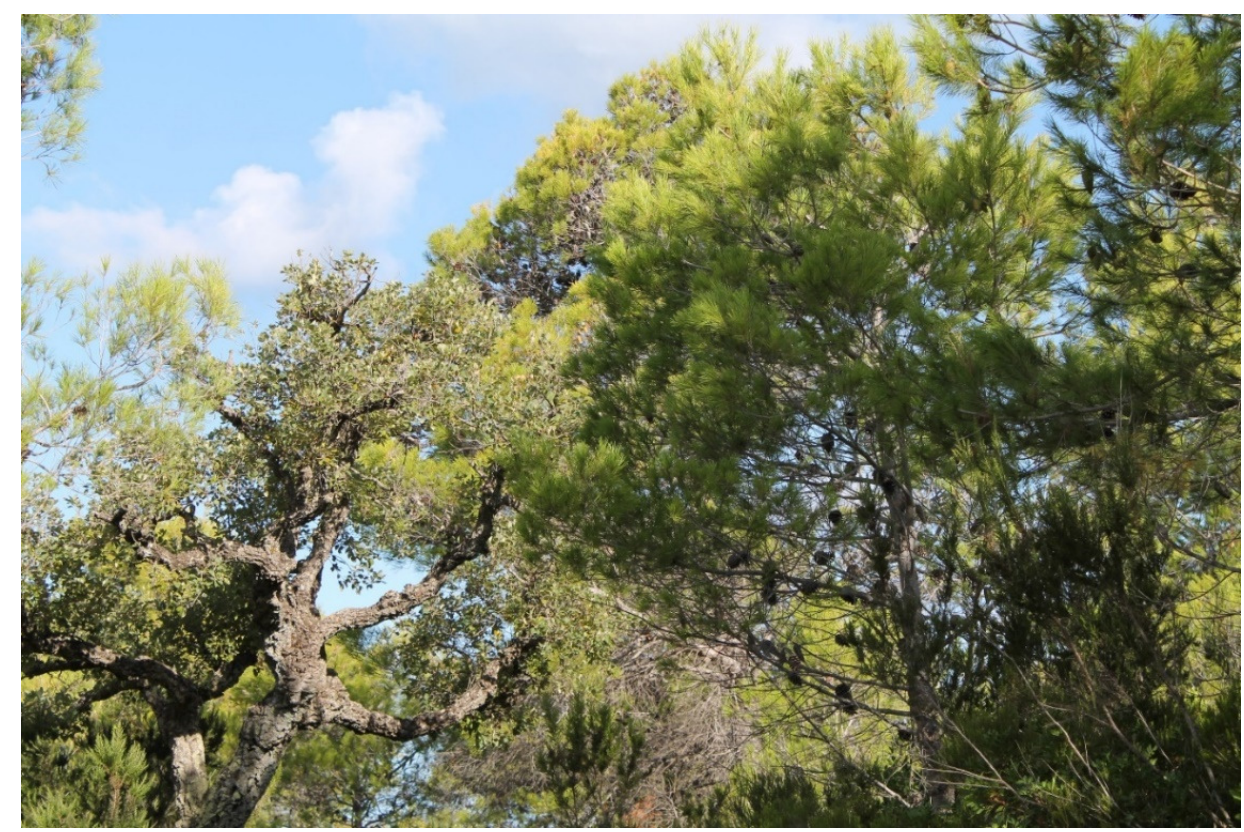

Figure 7. Concurrency between cork oak and Aleppo pine in Tunisia

\section{Management practices to limit Aleppo pine expansion into cork oak habitat}

Since the habitat of $Q$. suber is of high socio-ecological importance, several authors propose that appropriate silvicultural measures should aim to conserve species habitat. These measures should include : (i) gradual transformation of even-aged Q. suber stands to more diversified structures (uneven, multi-aged, and multistorey stands) in order to favor the natural regeneration of the species; (ii) grazing control; (iii) careful control of the understory maquis species through the improvement of the moisture conditions in order to favor seedling establishment and growth (Ciancio et al., 1986); and (vi) removal of P. halepensis trees in the Q. suber stands where the species has invaded, as early as possible, and preferably at the age before the trees reach fullreproduction. To limit the Aleppo pine expansion into cork oak habitat, it is necessary to integrate programs of development in the forest for sustainable development, and for territories and people and to introduce thinning to adapt to climate change to help reduce water competition in the forest, by controlling the understory vegetation, anticipating the regeneration cuts to stimulate seed dispersal, and promote sexual regeneration.

\section{Conclusions}

Climate change represents an important challenge for researchers studying forest silviculture and management. Several studies have shown that, under the effect of climate change, cork oak will disappear from a large area in the future and the rest will migrate to wet areas. In addition, the Aleppo pine is a plastic a species and will move into areas that are projected to have a humid climate. Other authors have shown that current cork oak habitat has been colonized in several places mainly by the Aleppo pine. In the future, it is possible that Aleppo pine will colonize cork oak habitat under the effect of climate change in North Africa and the Mediterranean basin, and thus, it is necessary to implement management and silviculture practices that help to alleviate the effects of climate change and thus the expansion of Aleppo pine into cork oak habitat as well. 


\section{Authors' Contributions}

KM did the field work, wrote and authored almost of the manuscript; WJ did field work authored part of manuscript and reviewed drafts of the paper; ASA, SN and YA reviewed drafts of the paper. All authors read and approved the final manuscript.

\section{Acknowledgements}

This project is carried out under the MOBIDOC scheme, funded by The Ministry of Higher Education and Scientific Research of Tunisia through the PromESsE project and managed by the ANPR. We thank Lazhar Hamdi (forest engineer) for his technical assistance as well as all the forest managers in the Northwestern Tunisia.

\section{Conflicts of Interest}

The authors declare that there are no conflicts of interest related to this article.

\section{References}

Acácio V, Dias FS, Catry FX, Rocha M, Moreira F (2016). Landscape dynamics in Mediterranean oak forests under global change: understanding the role of anthropogenic and environmental drivers across forest types. Global Change Biology 23(3):1199-1217. https://doi.org/10.1111/gcb.13487

Aitken SN, Yeaman S, Holliday JA, Wang T, Curtis-McLane S (2008). Adaptation, migration or extirpation: climate change outcomes for tree populations. Evolutionary Applications 1(1):95-111. https://doi.org/10.1111/j.1752-4571.2007.00013.X

Alberto FJ, Aitken SN, Alia R, Gonzalez-Martinez SC, Hanninen H, Kremer A, ... Savolainen O (2013). Potential for evolutionary responses to climate change evidence from tree populations. Global Change Biology 19(6):16451661. https://doi.org/10.1111/Gcb.12181

Aloui A, Ajaibi A, Benhamadi N (2006). Etude de la qualité du liège de reproduction des suberaies d'Ain Draham [Study of the quality of reproduction cork of Ain Draham cork oak stands]. Actes du séminaire, Gestion intégrée des forêts de chêne liège et de pin d'Alep. Annales de l'INRGREF 9(1):44-59.

Aranda I, Castro L, Alía R, Pardos JA, Gil L (2005). Low temperature during winter elicits differential responses among populations of the Mediterranean evergreen cork oak (Quercus suber). Tree Physiology 25(8):1085-1090. https://doi.org/10.1093/treephys/25.8.1085

Aranda I, Pardos M, Puértolas J, Jiménez MD, Pardos JA (2007). Water-use efficiency in cork oak (Quercus suber) is modified by the interaction of water and light availabilities. Tree Physiology 27(5):671-677. https://doi.org/10.1093/treephys/27.5.671

Araujo MB, Williams PH (2000). Selecting areas for species persistence using occurrence data. Biological Conservation 96(3):331-345. https://doi.org/10.1016/S0006-3207(00)00074-4

Athanasiadis N, Gerasimidis A (1986). Strofylia ecosystem of NW Peleoponisos and the phytosociological units, Thessaloniki. (in Greek).

Axelrod DI (1983) Biogeography of oaks in the Arcto-Tertiary province. Annals of the Missouri Botanical Garden 70(4):629-657. https://doi.org/10.2307/2398982

Barbero M, Loisel R, Quézel P, Richardson DM, Romane F (1998). Pines of the Mediterranean basin. In: Richardson DM (Ed). Ecology and Biogeography of Pinus. Cambridge University Press, Cambridge, pp 153-170.

Becker A, Bugmann H (2001). Global change and mountain regions (No. 0284-8015). IGBP, Stockholm.

Benito Garzón M, Sánchez de Dios R, Sainz Ollero H (2008). Effects of climate change on the distribution of Iberian tree species. Applied Vegetation Science 11(2):169-178. https://doi.org/10.3170/2008-7-18348 
Bertrand R, Perez V, Gegout JC (2012). Disregarding the edaphic dimension in species distribution models leads to the omission of crucial spatial information under climate change: the case of Quercus pubescens in France. Global Change Biology 18(8):2648-2660. https://doi.org/10.1111/j.1365-2486.2012.02679.x

Besson CK, Lobo-do-Vale R, Rodrigues ML, Almeida P, Herd A, Grant OM, ... Pereira JS (2014). Cork oak physiological responses to manipulated water availability in a Mediterranean woodland. Agricultural and Forest Meteorology 184:230-242. https://doi.org/10.1016/j.agrformet.2013.10.004

Brunetti M, Maugeri M, Nanni T, Navarra A (2002). Droughts and extreme events in regional daily Italian precipitation series. International Journal of Climatology 22(5):543-558. https://doi.org/10.1002/joc.751

Buckley YM, Rees M, Paynter Q, Lonsdale WM (2004). Modelling integrated weed management of an invasive shrub in tropical Australia. Journal of Applied Ecology 41(3):547-560. https://doi.org/10.1111/j.00218901.2004.00909.X

Bugalho MN, Caldeira MC, Pereira JS, Aronson J, Pausas JG (2011). Mediterranean cork oak savannas require human use to sustain biodiversity and ecosystem services. Frontiers in Ecology and the Environment 9(5):278-286. https://doi.org/10.1890/100084

Bussotti F, Pollastrini M, Holland V, Brüggemann W (2015). Functional traits and adaptive capacity of European forests to climate change. Environmental and Experimental Botany 111:91-113. https://doi.org/10.1016/j.envexpbot.2014.11.006

Cabezudo Artero B, Perez Latorre AV (2004). Las comunidades vegetales. [Plant communities] In: Herrera CM (Ed). El monte mediterraneo en Andalucia. Consejeria de Medio Ambiente, Junta de Andalucia, Sevilla, pp 29-45.

Cañellas I, Roig S, Montero G (2005). Pruning influence on acorn yield in cork-oak open woodland. International congress on silvopastoralism and sustainable management: silvopastoralism and sustainable land management. CABI Publishing, Lugo, pp 110-111. https://doi.org/10.1079/9781845930011.0110

Cañellas I, Roig S, Poblaciones MJ, Gea-Izquierdo G, Olea L (2007). An approach to acorn production in Iberian dehesas. Agroforestry Systems 70(1):3-9. https://doi.org/10.1007/s10457-007-9034-0

Caritat A, Gutiérrez E, Molinas M (2000). Influence of weather on cork-ring width. Tree Physiology 20(13):893-900. https://doi.org/10.1093/treephys/20.13.893

Caritat A, Molinas M, Gutiérrez E (1996). Annual cork-ring width variability of Quercus suber L. in relation to temperature and precipitation (Extremadura, southwestern Spain). Forest Ecology and Management 86(13):113-20. https://doi.org/10.1016/S0378-1127(96)03787-5

Chorana H, Dehane B, Beltrán RS (2019). Characterisation of the cork growth and quality of cork oak woodlands, NorthWest Algeria. International Journal of Environmental Studies 1-16. https://doi.org/10.1080/00207233.2019.1594290

Ciancio O, Cutini A, Mercurio R, Veracini A (1986). Sulla struttura della pineta di pino domestico di Alberese. [On the structure of the pine forest of Alberese]. Annali dell' Istituto Sperimentale della Selvicoltura, Arezzo XVII:171236.

CORKASSESS (2001). Field Assessment and modelling of cork production and quality. Final Report. Contract FAIR.C97.1438, (Brussels: European Commission Research Directorate General. Life Sciences Agriculture Agro-Industry; Fisheries and Forestry).

Correia RA, Bugalho MA, Franco AMA, Palmeirim JM (2017). Contribution of spatially explicit models to climate change adaptation and mitigation plans for a priority forest habitat. Mitigation and Adaptation Strategies for Global Change 23(3):371-386. https://doi.org/10.1007/s11027-017-9738-Z

Costa A, Barbosa I, Roussado C, Graça J, Spiecker H (2016). Climate response of cork growth in the Mediterranean oak (Quercus suber L.) woodlands of southwestern Portugal. Dendrochronologia 38:72-81. http://dx.doi.org/10.1016/j.dendro.2016.03.007

Costa A, Madeira M, Santos JL, Plieninger T (2014). Recent dynamics of Mediterranean evergreen oak wood pastures in Southwestern Iberia (Portugal, Spain). In: Hartel T, Plieninger T (Eds). European wood pastures in transition: a social-ecological approach. Earthscan from Routledge. Publisher, Routledge Earthscan, New York, pp 70-89.

Costa A, Nunes LC, Graça J, Spiecker H, Graça J (2015). Insights into the responsiveness of cork oak (Quercus suber L.) to bark harvesting. Economic Botany 69(2):171-84. https://doi.org/10.1007/s12231-015-9305-Z

Costa A, Pereira H, Oliveira A (2001). A dendroclimatological approach to diameter growth in adult cork-oak trees under production. Trees 15(7):438-443. https://doi.org/10.1007/s004680100119

Costa A, Pereira H, Oliveira A (2002). Influence of climate on the seasonality of radial growth of cork oak during a cork production cycle. Annals of Forest Science 59(4):429-437. https://doi.org/10.1051/forest:2002017 
Costa A, Pereira H, Oliveira A (2003). Variability of radial growth in cork-oak adult trees under cork production. Forest Ecology and Management 175(1-3):239-246. https://doi.org/10.1016/S0378-1127(02)00145-7

Costa GC, Nogueira C, Machado RB, Colli GR (2010). Sampling bias and the use of ecological niche modeling in conservation planning: a field evaluation in a biodiversity hotspot. Biodiversity and Conservervation 19(3):883899. https://doi.org/10.1007/s10531-009-9746-8

Costa Tenorio M, Morla Juaristi C, Sainz Ollero H (2005). Los Bosques Ibéricos. Una interpretacion geobotanica. Editorial Planeta, Barcelona.

Crispo E (2008). Modifying effects of phenotypic plasticity on interactions among natural selection, adaptation and gene flow. Journal of Evolutionary Biology 21(6):1460-1469. https://doi.org/10.1111/j.1420-9101.2008.01592.x

Dale VH, Joyce LA, Mcnulty S, Neilson RP, Ayres MP, Flannigan MD, ... Michael Wotton B (2001). Climate change and forest disturbances. BioScience 51(9):723-734. https://doi.org/10.1641/0006-3568(2001)051[0723:CCAFD]2.0.CO;2

David TS, Henriques MO, Kurz-Besson C, Nunes J, Valente F, Vaz M, ... David JS (2007). Water-use strategies in two co-occuring Mediterranean evergreen oaks: surviving the summer drought. Tree Physiology 27(6):793-803. https://doi.org/10.1093/treephys/27.6.793

David TS, Pinto CA, Nadezhdina N, Kurz-Besson C, Henriques MO, Quilhó T, ... David JS (2013). Root functioning, tree water use and hydraulic redistribution in Quercus suber trees: a modeling approach based on root sap flow. Forest Ecology and Management 307:136-146. https://doi.org/10.1016/j.foreco.2013.07.012

de Villalobos A.E, Schwerdt L (2020). Seasonality of feral horse grazing and invasion of Pinus halepensis in grasslands of the Austral Pampean Mountains (Argentina): management considerations. Biological Invasions 22:2941-2955. https://doi.org/10.1007/s10530-020-02300-x

de Villalobos AE, Zalba SM, Peláez DV (2011). Pinus halepensis invasion in mountain pampean grassland: effects of feral horses grazing on seedling establishment. Environmental Research 111(7):953-959. https://doi.org/10.1016/j.envies.2011.03.011

Deal RL, Smith N, Gates J (2017). Ecosystem services to enhance sustainable forest management in the US: moving from forest service national programmes to local projects in the Pacific Northwest. Forestry an International Journal of Forest Research 90(5):632-639. https://doi. org/10.1093/forestry/cpx025

Dehane B (2012). Incidences de l'état sanitaire des arbres du chêne-liége sur les accroissements annuels et la qualité du liège de deux suberaies oranaises : M'Sila (W Oran) et Zari-effet (W. Tlemcen). [Effects of the health status of cork oak trees on the annual growth and quality of the cork in two Oran cork groves: M'Sila (W Oran) and Zarieffect (W. Tlemcen)]. Ph.D. dissertation, University of Tlemcen, Algeria.

Dehane B, Ghefar M (2017). Etude de la variabilité de croissance du liège dans le Nord Algérien [Study of the variability of growth of the cork in Northern Algeria]. Revue Internationale de Géologie, de Géographie et d'Ecologie Tropicales 41:39-54.

Dehane BRT, Bouhraoua R, Ceca JLGD, González-Adrados JR (2013). Short communication. Effect of the health status on the cork production characteristics of Western Algeria cork oak stands. Forest Systems 22(1):138-146. http://dx.doi.org/10.5424/fs/2013221-02866

Delzon S, Urli M, Samalens JC, Lamy JB, Lischke H, Sin F, ... Porté AJ (2013). Field evidence of colonisation by Holm Oak, at the Northern Margin of its distribution range, during the anthropocene Period. PLoS One 8(11):1-8. http://dx.doi.org/10.1371/journal.pone.0080443

Diáz M, Campos P, Pulido FJ (1997). The Spanish dehesas : a diversity in land-use and wildlife. In: Pain DJ, Pienkowski MW (Eds). Farming and birds in Europe. Academic Press, Cambridge, UK.

Didham RK, Tylianakis JM, Hutchinson MA, Ewers RM, Gemmell NJ (2005). Are invasive species the drivers of ecological change? Trends in Ecology and Evolution 20(9):470-474. https://dx.doi.org/10.1016/j.tree.2005.07.006

Dobrowski SZ (2011). A climatic basis for microrefugia: the influence of terrain on climate. Global Change Biology 17(2):1022-1035. https://doi.org/10.1111/j.1365-2486.2010.02263.X

Dyderski MK, Paź S, Frelich LE, Jagodziński AM (2018). How much does climate change threaten European forest tree species distributions? Global Change Biology 24(3):1150-1163. https://dx.doi.org/10.1111/gcb.13925

FAO (2013). State of Mediterranean forests. Rome. Retrieved from http://www.fao.org/docrep/017/i3226e/i3226e.pdf

Ferreira A, Lopes F, Periera H (2000). Caractérisation de la croissance et la qualité du liège dans une région de production [Characterization of growth and quality of cork in one region of production]. Annals of Forest Sciences 57(2):187-193. https://dx.doi.org/10.1051/forest:2000169 
Fons-Esteve J, Paramo F (2003). Mapping sensitivity to desertification (DISMED). European Environmental Agency, European Topic Center, Terrestrial Environment, Internal Report.

Fortes MA, Rosa ME, Pereira H (2004). A Cortiça. ISTPress, Lisbon.

Fréjaville T, Fady B, Kremer A, Ducousso A, Benito Garzón M (2019). Inferring phenotypic plasticity and population responses to climate across tree species ranges using forest inventory data. Global Ecology and Biogeography 28:1259-1271. https://dx.doi.org/10.1111/geb.12930

Gandour M, Khouja ML, Toumi L, Triki S (2007). Morphological evaluation of cork oak (Quercus suber): mediterranean provenance variability in Tunisia. Annals of Forest Science 64(5):549-555. https://dx.doi.org/10.1051/forest:2007032

Garah K, Bentouati A (2019). Using the MaxEnt model for assessing the impact of climate change on the Aurasian Aleppo pine distribution in Algeria. African Journal of Ecolgy 1-12. https://dx.doi.org/10.1111/aje.12630

Gentilesca T, Camarero JJ, Colangelo M, Nolè A, Ripullone F (2017). Drought-induced oak decline in the western Mediterranean region: an overview on current evidences, mechanisms and management options to improve forest resilience. iForest 10(5):796-806. https://dx.doi.org/10.3832/ifor2317-010

Gerber S, Chadœuf J, Gugerli F, Lascoux M, Buiteveld J, Cottrell J, ... Kremer A (2014). High rates of gene flow by pollen and seed in oak populations across Europe. PLoS ONE 9(1):e85130. https://doi.org/10.1371/journal.pone.0085130

Ghalambor CK, McKay JK, Carroll SP, Reznick DN (2007). Adaptive versus non-adaptive phenotypic plasticity and the potential for contemporary adaptation in new environments. Functional Ecology 21(3):394-407. https://doi.org/10.1111/j.1365-2435.2007.01283.X

Ghalem A, Barbosa I, Bouhraoua R.T, Costa A (2018). Climate signal in cork-ring chronologies: case studies in Southwestern Portugal And Northwestern Algeria. Tree-Ring Research 74(1):15-27. http://dx.doi.org/10.3959/1536-1098-74.1.15

Gonzalez-Adrados JR, Gourlay I (1998). Applications of dendrochronology to Quercus suber L. In: Pereira H (Ed). Cork Oak and Cork. Proceedings of the European Conference on Cork Oak and Cork. Centro de Estudos Florestais, Lisboa, Portugal, pp 162-166.

Goubanova K, Li L (2007). Extremes in temperature and precipitation around the Mediterranean basin in an ensemble of future climate scenario simulations. Global and Planetary Change 57(1-2):27-42. http://dx.doi.org/10.1016/j.gloplacha.2006.11.012

Gourlay I, Pereira H (1998). The effect of bark stripping on wood production in cork oak (Quercus suber L.) and problems of growth ring definition. In: Pereira H (Ed). Cork Oak and Cork. Proceedings of the European Conference on Cork Oak and Cork. Centro de Estudos Florestais, Lisboa, Portugal, pp 99-107.

Govaerts R, Frodin DG (1998). World checklist and bibliography of Fagales. Royal Botanic Gardens, Kew, pp 408.

Gratani L, Catoni R, Varone L (2016). Evergreen species response to Mediterranean climate stress factors. iForest 9(6):946-953. https://doi.org/10.3832/ifor1848-009

Hidalgo PJ, Marin JM, Quijada J, Moreira JM (2008). A spatial distribution model of cork oak (Quercus suber) in southwestern Spain: A suitable tool for reforestation. Forest Ecology and Management 255(1):25-34. https://doi.org/do/10.1016/j.foreco.2007.07.012

Higgins SI, Richardson DM (1998). Pine invasions in the southern hemisphere: modelling interactions between organism, environment and disturbance. Plant Ecology 135(1):79-93. https://doi.org/10.1023/A:1009760512895

IPCC (2014). Climate Change 2014: Synthesis Report. Contribution of Working Groups I, II and III to the Fifth Assessment Report of the Intergovernmental Panel on Climate Change. IPCC, Geneva.

Kelbel P, Adamčíková Z (2011). Selected invasive and expansive tree species in conditions of the botanical garden of P.J. Šafárik University in Košice. Thaiszia Journal of Botany 21:141-152. http://www.bz.upjs.sk/thaiszia

Klausmeyer KR, Shaw MR (2009). Climate change, habitat loss, protected areas and the climate adaptation potential of species in Mediterranean ecosystems worldwide. PLoS ONE 4(7):1-9. https://doi.org/10.1371/Journal.Pone.0006392

Knapic S, Louzada JL, Leal S, Pereira H (2007). Radial variation of wood density components and ring width in cork oak trees. Annals of Forest Science 64(2):211-218. https://doi.org/10.1051/forest:2006105

Kremer A, Potts BM, Delzon S (2014). Genetic divergence in forest trees : understanding the consequences of climate change. Functional Ecology 28(1):22-36. https://doi.org/10.1111/1365-2435.12169

Langdon B, Pauchard A, Aguayo M (2010). Pinus contorta invasion in the Chilean Patagonia local patterns in a global context. Biology Invasions 12(12):3961-3971. https://doi.org/10.1007/s10530-010-9817-5 
Lauw A, Oliveira V, Lopes F, Pereira H (2018). Variation of cork quality for wine stoppers across the production regions in Portugal. European Journal of Wood and Wood Products 76(1):123-132. https://doi.org/10.1007/s00107-017-1196-5

Lavi A, Perevolotsky A, Kigel J, Noy-Meir I (2005). Invasion of Pinus halepensis from plantations into adjacent natural habitats. Applied Vegetation Science 8(1):85-92. https://doi.org/10.1111/j.1654-109X.2005.tb00632.X

Le Maitre DC, van Wilgen BW, Gelderblom CM, Bailey C, Chapman RA, Nel JA (2002). Invasive alien trees and water resources in South Africa: case studies of the costs and benefits of management. Forest Ecology and Management 160(1-3):143-159. https://doi.org/10.1016/S0378-1127(01)00474-1

Leal S, Nunes E, Pereira H (2008). Cork oak (Quercus suber L.) wood growth and vessel characteristics variations in relation to climate and cork harvesting. European Journal of Forest Research 127(1):33-41. https://doi.org/10.1007/s10342-007-0180-8

Leal S, Sousa VB, Pereira H (2006). Within and between-tree variation in the biometry of wood rays and fibres in cork oak (Quercus suber L.). Wood Science and Technology 40(7):585-597. https://doi.org/10.1007/s00226-006-0073-X

Ledgard N (1988). The spread of introduced trees in New Zealand's rangelands - South Island high country experience. Review-Tussock Grassland and Mountain Lands Institute 44:1-8

Ledgard NJ (2009). Wilding control guidelines for farmers and land managers. New Zealand Plant Protection 62:380386. https://doi.org/10.30843/nzpp.2009.62.4879

Leite C, Oliveira V, Lauw A, Pereira H (2019). Cork rings suggest how to manage Quercus suber to mitigate the effects of climate changes. Agricultural and Forest Meteorology 266-267:12-19. https://doi.org/10.1016/j.agrformet.2018.11.032

Lemes P, Melo AS, Loyola RD (2014). Climate change threatens protected areas of the Atlantic Forest. Biodiversity and Conservation 23(2):357-368. https://doi.org/10.1007/s10531-013-0605-2

Lenoir J, Gegout JC, Marquet PA, de Ruffray P, Brisse H (2008). A significant upward shift in plant species optimum elevation during the 20th century. Science 320(5884):1768-1771. https://doi.org/10.1126/science.1156831

Lopez Gonzalez GA (2007). Guia de los arboles y arbustos de la Penınsula Iberica y Baleares, 3rd edn. Ediciones MundiPrensa, Madrid.

Lopez-Tirado J, Hidalgo PJ (2016a). Predictive modelling of climax oak trees in southern Spain: insights in a scenario of global change. Plant Ecology 217(4):451-463. https://doi.org/10.1007/s11258-016-0589-6

Lopez-Tirado J, Hidalgo PJ (2016b). Ecological niche modelling of three Mediterranean pine species in the south of Spain: a tool for afforestation/reforestation programs in the twenty-first century. New Forests 47(3):411-429. https://doi.org/10.1007/s11056-015-9523-3

Lopez-Tirado J, Vessella F, Schirone B, Hidalgo PJ (2018). Trends in evergreen oak suitability from assembled species distribution models: assessing climate change in south-western Europe. New Forests (2018) 49(4):471-487. https://doi.org/10.1007/s11056-018-9629-5

Mack RN, Simberloff D, Lonsdale WM, Evans H, Clout M, Bazzaz F (2000). Biotic invasions: causes, epidemiology, global consequences and control. Ecological Applications 10(3):689-710. https://doi.org/do/10.2307/2641039.

Manso R, Pukkala T, Pardos M, Miina J, Calama R (2014). Modelling Pinus pinea forest management to attain natural regeneration under present and future climatic scenarios. Canadian Journal of Forest Research 44(3):250-262. https://doi.org/10.1139/cjif-2013-0179

Mendes MP, Ribeiro L, David TS, Costa A (2016). How dependent are cork oak (Quercus suber L.) woodlands on groundwater? A case study in southwestern Portugal. Forest Ecology and Management 378:122-130. https://doi.org/10.1016/j.foreco.2016.07.024

Menitsky YL (2005). Oaks of Asia. Science Publishers, Enfield.

Moretti V, Di Bartolomei R, Sorgi T, Aromolo R, Salvati L (2015). Soil water deficit and climate conditions during the dry season along the coastal-inland gradient in Castelporziano forest, central Italy. Rendiconti Lincei Scienze Fisiche e Naturali 26:283-288. https://doi.org/10.1007/s12210-014-0336-7

Munzbergova Z, Hadincova V, Wild J, Herben T, Maresova J (2010). Spatial and temporal variation in dispersal pattern of an invasive pine. Biological Invasions 12(8):2471-2486. https://doi.org/10.1007/s10530-009-9656-4

Nathan R, Ne'eman G (2004). Spatiotemporal dynamics of recruitment in Aleppo pine (Pinus halepensis Miller). Plant Ecology 171(1-2):123-137. https://doi.org/10.1023/b:vege.0000029379.32705.0f 
Nathan R, Safriel UN, Noy-Meir I, Schiller G (1999). Seed release without fire in Pinus halepensis, a Mediterranean serotinous wind-dispersed tree. Journal of Ecology 87(4):659-669.

https://doi.org/10.1046/j.1365-2745.1999.00382.X

Natividade JV (1950). Subericultura. Direcção-Geral dos Serviços Florestais e Aquícolas.

Nixon KC (2006). Global and neotropical distribution and diversity of oak (genus Quercus) and oak forests. In: Kappelle M (Ed). Ecology and conservation of neotropical Montane oak forests. Ecological studies series, vol 185. Springer-Verlag, Berlin, pp 3-13.

Nunes E (1996). Estudo da influência da precipitação e temperatura no crescimento juvenil de Quercus suber L. a través dos anéis anuais de crescimento. [Study of the influence of precipitation and temperature on juvenile growth of Quercus suber L. through annual growth rings]. Dissertation, Instituto Superior de Agronomia, Universidade Técnica de Lisboa, Lisboa, Portugal.

Nunez M.A, Chiuffo M.C, Torres A, Paul T, Dimarco R.D, Raal P, ... Richardson DM (2017). Ecology and management of invasive Pinaceae around the world: progress and challenges. Biological Invasions 19(11):3099-3120. https://doi.org/10.1007/s10530-017-1483-4

Oliveira G, Correia O, Martins-Loução MA, Catarino FM (1994). Phenological and growth patterns of the Mediterranean oak Quercus suber L. Trees 9(1):41-46. https://doi.org/10.1007/BF00197868

Oliveira G, Costa A (2012). How resilient is Quercus suber L. to cork harvesting? A review and identification of knowledge gaps. Forest Ecology and Management 270:257-272. https://doi.org/10.1016/j.foreco.2012.01.025

Oliveira V, Lauw A, Pereira H (2016). Sensitivity of cork growth to drought events: insights from a 24-year chronology. Climate Change 137(1-2):261-274. https://doi.org/10.1007/s10584-016-1680-7.

Parmesan C (2006). Ecological and evolutionary responses to recent climate change. Annual Review of Ecology, Evolution, and Systematics 37:637-669. http://www.jstor.org/stable/30033846

Parmesan C, Yohe G (2003). A globally coherent fingerprint of climate change impacts across natural systems. Nature 421(6918):37-42. https://doi.org/do/10.1038/nature01286

Pecchi M, Marchi M, Moriondo M, Forzieri G, Ammoniaci M, Bernetti I, ... Chirici G (2020). Potential impact of climate change on the forest coverage and the spatial distribution of 19 key forest tree species in Italy under RCP4.5 IPCC trajectory for 2050s. Forests 11:934-952. https://doi.org/10.3390/f11090934

Peñuelas J, Boada M (2003). A global change-induced biome shift in the Montseny mountains (NE Spain). Global Change Biology 9(2):131-140. https://doi.org/10.1046/j.1365-2486.2003.00566.x

Pereira H (2007). Cork: biology, production and uses. Elsevier, Amsterdam.

Pereira H (2015). The rationale behind cork properties: a review of structure and chemistry. Bioresources 10(3):62076229. https://doi.org/10.15376/biores. 10.3.Pereira

Peterken GF (2001) Ecological effects of introduced tree spe-cies in Britain. Forest Ecology and Management 141(12):31-42. https://doi.org/10.1016/S0378-1127(00)00487-4

Plieninger T, van der Horst D, Schleyer C, Bieling C (2014). Sustaining ecosystem services in cultural landscapes. Ecology and Society 19(2):59-64. https://doi.org/10.5751/ES-06159-190259

Pons J, Pausas JG (2006). Oak regeneration in heterogeneous landscape: the case of fragmented Quercus suber forests in the eastern Iberian Peninsula. Forest Ecology and Management 231(1-3):196-204. https://doi.org/10.1016/j.foreco.2006.05.049

Prach K, Wade PM (1992). Population characteristics of expansive perennial herbs. Preslia 64:45-51.

Pyšek P, Richardson DM, Rejmánek M, Webster G, Williamson M, Kirschner J (2004). Alien plants in checklists and floras: towards better communication between taxonomists and ecologists. Taxon 53(1):131-143. https://doi.org/10.2307/4135498

Rambal S, Ourcival JM, Joffre R, Mouillot F, Nouvellon Y, ... Rocheteau A (2003). Drought controls over conductance and assimilation of a Mediterranean evergreen ecosystem: Scaling from leaf to canopy. Global Change Biology 9(12):1813-1824. https://doi.org/10.1111/j.1365-2486.2003.00687.x

Ramırez-Valiente JA, Sanchez-Gomez D, Aranda I, Valladares F (2010). Phenotypic plasticity and local adaptation in leaf ecophysiological traits of 13 contrasting cork oak populations under different water availabilities. Tree Physiology 30(5):618-627. https://doi.org/10.1093/treephys/tpq013

Ramırez-Valiente JA, Valladares F, Huertas AD, Granados S, Aranda I (2011). Factors affecting cork oak growth under dry conditions: local adaptation and contrasting additive genetic variance within populations. Tree Genetics and Genomes 7(2):285-295. https://doi.org/10.1007/s11295-010-0331-9 
Richardson DM (2001). Plant invasions. In: Levin S (Ed). Encyclopedia of Biodiversity. Academic Press, San Diego, pp 677-688.

Richardson DM, Higgins SI (1998). Pines as invaders in the Southern Hemisphere. In: Richardson DM (Ed). Ecology and Biogeography of Pinus. Cambridge University Press, Cambridge, pp 450-473.

Richardson DM, Williams PA, Hobbs RJ (1994). Pine invasions in the Southern hemisphere: determinants of spread and invadability. Journal of Biogeography 21(5):511-527. https://doi.org/10.2307/2845655

Rodewald AD, Arcese P (2016). Direct and indirect interactions between landscape structure and invasive or oberabundant species. Current Landscape Ecology Reports 1(1):30-39.

https://doi.org/10.1007/s40823-016-0004-y

Scheffers BR, Meester LD, Bridge TCL, Hoffmann AA, Pandolfi JM, Corlett RT, ... Watson JEM (2016). The broad footprint of climate change from genes to biomes to people. Science 354(6313):719-729. https://dx.doi.org/10.1126/science.aaf 7671

Schirone B, Spada F, Piovesan G, Simeone MC (2015). Phenorhythms and forest refugia. In: Box EO, Fujiwara K (Eds). Warm-temperate deciduous forests around the Northern Hemisphere. Springer, London, pp 213-223.

Simberloff D (2010). Invasive species. In Conservation biology for all, Sodhi NS, Ehrlich PR (Eds). Oxford University Press, New York pp 131-152.

Simberloff D, Nuñez MA, Ledgard NJ, Pauchard A, Richardson DM, Sarasola M, ... Ziller SR (2010). Spread and impact of introduced conifers in South America: lessons from other southern hemisphere regions. Austral Ecology 35(5):489-504. https://doi.org/10.1111/j.1442-9993.2009.02058.x

Sousa VB, Leal S, Quilhó T, Pereira H (2009). Characterization of cork oak (Quercus suber) wood anatomy. Iawa Journal 30(2):149-161. https://doi.org/10.1163/22941932-90000210

Sun S, Zhang Y, Huang D, Wang H, Cao Q, Fan P, ... Wang R (2020). The effect of climate change on the richness distribution pattern of oaks (Quercus L.) in China. Science of the Total Environment 744:140786-140797. https://doi.org/10.1016/j.scitotenv.2020.140786

Tapias R, Climent J, Pardos JA, Gil L (2004). Life histories of Mediterranean pines. Plant Ecology 171:53-68. https://doi.org/10.1023/B:VEGE.0000029383.72609.fO

Thuiller W, Lavergne S, Roquet C, Boulangeat I, Lafourcade B, Araújo MB (2011). Consequences of climate change on the tree of life in Europe. Nature 470(7335):531-534. https://dx.doi.org/10.1038/nature09705

Trumbore S, Brando P, Hartmann H (2015). Forest health and global change. Science 349(6250):814-818. https://doi.org/10.1126/science.aac6759

Van der Meersch V, Zo-Bi I C, Amani BHK, N'dja JK, N'Guessan AE, Herault B (2020). Causes and consequences of Cedrela odoratainvasion in West African semi-deciduous tropical forests. Biological Invasions. https://doi.org/10.1007/s10530-020-02381-8

Varela MC (2001). The EUFORGEN Quercus suber Network and the research projects for the evaluation of genetic variability of cork oak. In: Mediterranean Oaks Network, Report of the first meeting, 12-14 October 2000, Antalya, Turkey. International Plant Genetic Resources Institute, Rome, Italy, 2001. ISBN 92-9043-469-4 IPGRI Via dei Tre Denari, 472/a 00057 Mac-carese (Fiumicino) Rome, Italy International Plant Genetic Resources Institute, pp 6.

Vennetier M, Girard F, Didier C, Ouamim S, Ripert C, Misson L, ... NDYAYE A (2011). Adaptation phénologique du pin d'Alep au changement climatique. [Phenological adaptation of Aleppo pine to climate change]. Forêt méditerranéenne T. XXXII (2):151-166.

Vennetier M, Vila B, Liang EY, Guibal F, Ripert C, Chandioux O (2005). Impact du changement climatique sur la productivité forestière et le déplacement d'une limite bioclimatique en région méditerranéenne française. [Impact of climate change on forest productivity and the displacement of a bioclimatic limit in the French Mediterranean region]. Ingénieries 44:49-61.

Vericat P, Pique M, Serrada R (2012). Gestion adaptativa al cambio global en masas de Quercus mediterraneos. [Adaptive management to global change in masses of Quercus mediterranean Quercus]. Centre Tecnologic Forestal de Catalunya, Lleida.

Vessella F, López-Tirado J, Simeone MC, Bartolomeo S, Hidalgo PJ (2017). A tree species range in the face of climate change: cork oak as a study case for the Mediterranean biome. European Journal of Forest Research 136:555569. https://doi.org/10.1007/s10342-017-1055-2 
Vessella F, Schirone B (2013). Predicting potential distribution of Quercus suber in Italy based on ecological niche models: Conservation insights and reforestation involvements. Forest Ecology and Management 304:150161.https://dx.doi.org/10.1016/j.foreco.2013.05.006

Woziwoda B, Kopeć D, Witkowski J (2014). The negative impact of intentionally introduced Quercus rubra L. on a forest community. Acta Societatis Botanicorum Poloniae 83(1):39-49. https://doi.org/10.5586/asbp.2013.035

Zalba SM, Cuevas YA, Boó RM (2008). Invasion of Pinus halepensis Mill. following a wildfire in an Argentine grassland nature reserve. Journal of Environmental Management 88(3):539-546. https://doi.org/10.1016/j.jenvman.2007.03.018
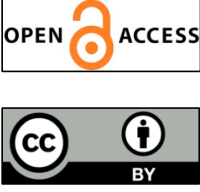

The journal offers free, immediate, and unrestricted access to peer-reviewed research and scholarly work. Users are allowed to read, download, copy, distribute, print, search, or link to the full texts of the articles, or use them for any other lawful purpose, without asking prior permission from the publisher or the author.

License - Articles published in Notulae Botanicae Horti Agrobotanici Cluj-Napoca are Open-Access, distributed under the terms and conditions of the Creative Commons Attribution (CC BY 4.0) License. (C) Articles by the authors; UASVM, Cluj-Napoca, Romania. The journal allows the author(s) to hold the copyright/to retain publishing rights without restriction. 